\title{
STRATEGI HUBUNGAN MASYARAKAT DALAM MENINGKATKAN PARTISIPASI AKTIF WALI MURID DI MTS. IHYAUL ULUM BLURI SOLOKURO LAMONGAN
}

\author{
Yogi Kurniawan Prayetno") \\ Universitas Islam Darul Ulum (UNISDA) Lamongan \\ Email: yogikurniawanprayetno@gmail.com¹
}

\begin{abstract}
Abstraksi: Strategi humas dalam meningkatkan partisipasi aktif wali murid merupakan salah satu cara untuk membina dan mengembangkan hubungan yang harmonis antara sekolah dan wali murid. MTs. Ihyaul Ulum Bluri Solokuro Lamongan adalah salah satu lembaga pendidikan yang dibangun melalui kegiatan hubungan masyarakat, dimana penggunaan kegiatan hubungan masyarakat memajukan dari segi mutu lembaga pendidikan tersebut. Dengan demikian, sekolah menyadari pentingnya dukungan wali murid dalam rangka memajukan dan mengembangkan pendidikannya. Jenis penelitian ini termasuk penelitian kualitatif, dengan mencari data kemudian dianalisis dengan menggunakan metode deskriptif. Data yang dicari menggunakan teknik wawancara, observasi dan dokumentasi. Hasil dari penelitian ini menunjukkan bahwa strategi humas yang ada di MTs. Ihyaul Ulum Bluri Solokuro Lamongan merupakan usaha-usaha mewujudkan peranan sekolah dalam memberikan pendidikan yang berkualitas. Dalam pemenuhan kebutuhan tersebut, strategi humas dilakukan secara sistematis. Mulai dari kegiatan perencanaan, humas dalam meningkatkan partisipasi aktif wali murid yang dilaksanakan berdasarkan rapat kerja setiap awal semester, hal tersebut mengacu pada analisis kebutuhan dan keinginan masyarakat internal maupun eksternal. Kemudian pelaksanaan humas dilaksanakan sesuai dengan jadwal yang telah ditentukan, adapun jenis partisipasi aktif wali murid yang telah terlaksana yaitu: 1) Partisipasi tenaga atau fisik, 2) Partisipasi ide atau pemikiran dan 3) Partisipasi dana. Lalu, evaluasi program, Dalam pelaksanaan evaluasi, MTs. Ihyaul Ulum Bluri melakukan rapat per enam bulan sekali yakni sebelum semester gasal, sebelum semester genap dan menjelang kenaikan. Adapun faktor pendukung bidang humas untuk melaksanakan program adalah: antusias wali murid dalam mendukung kegiatan sekolah dan juga warga sekolah yang memiliki rasa memiliki dan semangat yang tinggi demi kemajuan sekolah serta ikatan persaudaraan yang kuat. Sedangkan faktor penghambatnya adalah wali murid kurang mengerti tentang dunia digital, dimana hal tersebut merupakan peluang terbesar bidang humas untuk menjalankan programnya dan kurangnya pendanaan sekaligus kurangnya profesionalitas praktisi humas. Adapun dari hasil penelitian tersebut disarankan untuk kedepannya praktisi humas lebih maksimal dalam mengaplikasikan kompetensi serta kode etik humas dengan baik agar mempermudah lembaga pendidikan untuk melakukan koordinasi, perencanaan, negosiasi serta membangun hubungan baik antara lembaga pendidikan dengan wali murid.
\end{abstract}

Kata Kunci : Strategi Humas, Partisipasi Aktif 


\begin{abstract}
The public relations strategy in increasing the active participation of parents is one way to foster and develop a harmonious relationship between the school and the parents. MTs. Ihyaul Ulum Bluri Solokuro Lamongan is one of the educational institutions built through public relations activities, where the use of public relations activities advances the quality of the educational institution. This type of research includes qualitative research, by searching for data and then analyzing it using descriptive methods. The data sought using interview, observation and documentation techniques. The results of this study indicate that the public relations strategy in MTs. Ihyaul Ulum Bluri Solokuro Lamongan is an effort to realize the role of schools in providing quality education. In meeting these needs, the public relations strategy is carried out systematically. Starting from planning activities, public relations in increasing the active participation of parents who are carried out based on work meetings at the beginning of each semester, this refers to an analysis of the needs and desires of the internal and external community. Then the implementation of public relations is carried out according to a predetermined schedule, as for the types of active parental participation that have been carried out, namely: 1) Energy or physical participation, 2) Ideas or thoughts participation and 3) Fund participation. Then, program evaluation. In implementing the evaluation, MTs. Ihyaul Ulum Bluri holds a meeting every six months, namely before the odd semester, before the even semester and before the increase. The supporting factors in the field of public relations to carry out the program are: enthusiastic parents of students in supporting school activities and also school residents who have a high sense of belonging and enthusiasm for the progress of the school and strong brotherly bonds. Meanwhile, the inhibiting factor is that the parents do not understand the digital world, which is the biggest opportunity for the public relations field to run its program and the lack of funding as well as the lack of professionalism of public relations practitioners. As for the results of this study, it is recommended that in the future public relations practitioners are more optimal in applying the competence and code of ethics of public relations properly to make it easier for educational institutions to coordinate, plan, negotiate and build good relations between educational institutions and guardians of students.
\end{abstract}

Keywords : Public Relations Strategy, Active Participation

\title{
Pendahuluan
}

Hubungan Sekolah dengan wali murid pada hakikatnya merupakan sarana yang sangat berperan dalam membina dan mengembangkan potensi peserta didik di sekolah. Dalam hal ini, sekolah sebagai sistem sosial merupakan bagian integral dari sistem sosial yang lebih besar, yaitu masyarakat. Sekolah dan wali murid memiliki hubungan yang sangat erat dalam mencapai tujuan sekolah atau pendidikan secara efektif dan efisien. Selain itu, sekolah juga harus menunjang pencapaian tujuan atau pemenuhan kebutuhan wali murid, khususnya kebutuhan pendidikan. Lembaga pendidikan utamanya sekolah, tidak bisa terlepas dari strategi, karena strategi merupakan komponen integral yang tidak dapat dipisahkan dari proses pendidikan secara keseluruhan. Tanpa adanya manajemen, tidak mungkin tujuan pendidikan dapat diwujudkan secara optimal, efektif dan efisien. ${ }^{1}$ Pada kerangka inilah tumbuh kesadaran akan pentingnya memberdayakan masyarakat dan lingkungan sekitar sekolah. Hal ini diharapkan agar tercapai tujuan hubungan sekolah dengan masyarakat, yaitu meningkatnya kinerja sekolah dan terlaksananya proses pendidikan di sekolah secara produktif, efektif dan efisien, sehingga menghasilkan lulusan yang produktif dan berkualitas. ${ }^{2}$

\footnotetext{
${ }^{1}$ E.Mulyasa, Manajemen Berbasis Sekolah, Konsep Strategi dan Implementasi, (Bandung: PT. Remaja Rosdakarya, 2003), 20.

2 E.Mulyasa, Menjadi Kepala Sekolah Profesional, (Bandung: PT. Remaja Rosdakarya, 2004), Cet.3, 166.
} 
Dan disamping itu, sekolah juga harus mengetahui dengan jelas apa kebutuhan, harapan dan tuntutan wali murid, terutama terhadap sekolah. Dengan kata lain, antara sekolah dan wali murid harus dibina dan dikembangkan suatu hubungan yang harmonis. ${ }^{3}$ Hal ini berarti bahwa sekolah merupakan bagian yang tak terpisahkan dari wali murid. Hubungan serasi, terpadu, serta timbal balik yang diciptakan dan dilaksanakan agar peningkatan mutu pendidikan dan pembangunan dapat saling menunjang. ${ }^{4}$

Humas dalam menjalin hubungan dengan publik haruslah mempunyai strategi humas, khususnya dalam menjalin hubungan dengan publik eksternal sekolah. Menjalin hubungan dan komunikasi yang baik dengan publik merupakan salah satu peran dan fungsi humas. Hubungan ini harus terbina dengan baik dan harmonis guna pencapaian tujuan bersama, yaitu tujuan lembaga pendidikan. Humas bertindak sebagai komunikator atau mediator untuk membantu mendengar apa yang menjadi keinginan dan harapan publik, yang mana biasanya dilakukan melalui contact humas maupun surat dari publiknya. ${ }^{5}$

Sebagaimana disebutkan dalam Undang-undang Nomor 20 Tahun 2003 pasal 3 tentang Sisdiknas menyatakan, bahwa: "Partisipasi masyarakat merupakan sebuah kontribusi dari orangorang melalui pemikiran ide gagasan, atau melalui tenaga jasmaninya yang memang seharusnya dapat memberikan pengaruh terhadap ujung tombak peningkatan mutu pendidikan. Oleh karena itu, peranan masyarakat adalah bagian terpenting dalam mendobrak kualitas pendidikan secara komprehensif mampu melahirkan peserta didiknya sebagai insan yang beriman, bertakwa kepada Tuhan Yang Maha Esa, berakhlak mulia, sehat, berilmu, cakap, kreatif, mandiri, dan menjadi warga Negara yang demokrasi serta bertanggung jawab".

MTs. Ihyaul Ulum Bluri adalah salah satu lembaga pendidikan yang dibangun melalui kegiatan publik relation (humas) dalam lembaga pendidikannya, dimana penggunaan kegiatan hubungan masyarakat memajukan dari segi mutu lembaga pendidikan tersebut. Dengan demikian, sekolah menyadari pentingnya dukungan wali murid dalam rangka memajukan dan mengembangkan pendidikannya. Hal itu dilakukan oleh sekolah agar lebih banyak wali murid yang tertarik untuk menyekolahkan anaknya disekolah tersebut dan agar partisipasi wali murid dengan sekolah dapat meningkat dengan demikian, wali murid diajak untuk bersama-sama untuk membangun dan meningkatkan sekolah. Hal tersebut dapat tercapai manakala pihak masyarakat dan sekolah memperhatikan manajemen humas, agar dapat berjalan dengan efektif dan efisien.

\section{Metode Penelitian}

Pendekatan penelitian yang dipakai oleh peneliti adalah pendekatan kualitatif. Penelitian kualitatif adalah suatu penelitian yang ditujukan untuk memahami fenomena tentang apa saja yang terjadi dan dialami oleh subjek penelitian misalnya perilaku, persepsi, motivasi, tindakan dan lain-lain yang diteliti secara holistik dan dengan cara deskripsi dalam bentuk kata-kata dan bahasa. ${ }^{7}$ Dipilihnya pendekatan penelitian kualitatif karena pendekatan tersebut sesuai dengan penelitian ini yang mengharuskan peneliti terjun langsung untuk mengumpulkan data dan mengamati subjek penelitian secara intensif. Jenis penelitian yang digunakan dalam penelitian ini adalah jenis studi kasus, studi kasus merupakan penelitian yang mendalam tentang individu, satu kelompok, satu organisasi, satu program kegiatan, dan sebagainya dalam waktu tertentu. Tujuannya untuk memperoleh diskripsi yang utuh dan mendalam dari sebuah entitas. Studi kasus menghasilkan data untuk selanjutnya dianalisis untuk menghasilkan teori.

\footnotetext{
3 Ibid., 165.

${ }^{4}$ Ary H. Gunawan, Administrasi Sekolah Administrasi Pendidikan Mikro, (Jakarta: PT. Rineka Cipta, 1996$), 187$.

.5 Soemirat, Dasar-Dasar Public Relations (Bandung: Remaja Rosdakarya, 2008). 15

${ }^{6}$ Undang-undang Sistem Pendidikan Nasional, (Yogyakarta: Pustaka Pelajar, 2005), 8.

${ }^{7}$ Lexy J. Moleong, Metodologi Penelitian Kualitatif, (Bandung: PT Remaja Rosdakarya, 2005), 6.
} 
Sebagaimana prosedur perolehan data penelitian kualitatif, data studi kasus diperoleh dari wawancara, observasi, dan arsip. ${ }^{8}$ penelitian ini, peneliti akan meneliti tentang Strategi Humas dalam Meningkatkan Partisipasi Aktif Wali Murid di MTs. Ihyaul Ulum Bluri. Alasan menggunakan penelitian kualitatif, karena peneliti ingin mengetahui proses strategi praktisi humas dalam mengadakan kegiatan-kegiatan yang bertujuan menanamkan nilai nilai pada wali murid, sehingga mampu berpartispasi aktif dalam setiap kegiatan kelembagaan.

\section{Lokasi Penelitian}

Latar penelitian berisi penjelasan tentang lokasi, rentang waktu, dan atau subjek penelitian, peneliti perlu menjelaskan alasan memilih lokasi, rentang waktu, dan atau subjek penelitian. Latar penelitian adalah tempat di mana peneliti akan melakukan penelitian. Adapun lokasi penelitiannya berada di MTs Ihyaul Ulum Bluri yang berlokasi di Jalan Pantenan No 412 Desa Bluri Kecamatan Solokuro Kabupaten Lamongan. Dipilihnya MTs Ihyaul Ulum Bluri sebagai tempat penelitian karena lembaga pendidikan ini memiliki kekuatan yang baik dalam menjalin hubungan dengan masyarakatnya. MTs. Ihyaul Ulum Bluri telah berdiri sejak tahun 1987 dan telah mengalami pergantian kepala sekolah sebanyak 4 kali. Jumlah tenaga pendidik 25 orang dengan rincian 1 PNS dan 24 GBPNS, Jumlah tenaga kependidikan 4 orang dan mempunyai 73 Peserta didik dengan rincian kelas VII berjumlah 26 Peserta didik, kelas VIII berjumlah 23 Peserta didik dan kelas IX berjumlah 24 Peserta didik. Mayoritas pekerjaan orang tua siswa adalah petani dan wiraswasta karena letaknya di pedesaan.

\section{Data dan Sumber Data}

Secara umum sumber data penelitian kualitatif adalah tindakan dan perkataan manusia dalam suatu latar yang bersifat alamiah. ${ }^{9}$

a. Sumber Data Primer

Sumber Data primer adalah sumber data yang langsung memberikan data kepada pengumpul data. Dalam penelitian ini, sumber data primer yang diperoleh oleh peneliti adalah: hasil observasi dan wawancara dengan Kepala Sekolah, Waka Humas, Waka Kesiswaan MTs. Ihyaul Ulum Bluri serta Komite Sekolah, Tokoh Masyarakat, dan Wali Murid,

b. Sumber Data Sekunder

Sumber data sekunder adalah sumber yang tidak langsung memberikan data kepada pengumpul data, misalnya lewat orang lain atau dokumen. Sumber data sekunder yang diperoleh peneliti adalah data yang diperoleh langsung dari pihak-pihak yang berkaitan berupa data-data sekolah dan berbagai literatur yang relevan.

\section{Tekhnik Pengumpulan Data}

a. Metode Observasi

Observasi adalah pengamatan dan pencatatan secara sistematis terhadap gejala yang tampak pada objek penelitian. Pengamatan dan pencatatan ini dilakukan terhadap objek ditempat terjadi atau berlangsungnya peristiwa. ${ }^{10}$ Dalam penelitian ini penulis menggunakan alat bantu berupa buku catatan, dan kamera. Metode ini digunakan untuk melihat secara langsung pelaku, tempat dan aktivitas yang mungkin tidak terungkap dalam sesi wawancara.

b. Metode Wawancara

Wawancara adalah bentuk komunikasi antara dua orang, melibatkan seseorang yang ingin memperoleh informasi dari seorang lainnya dengan mengajukan pertanyaan-pertanyaan, berdasarkan

\footnotetext{
^ Mudjia Raharjo, "Materi kuliah Metodologi Penelitian Kualitatif”, Pascasarjana UIN Maliki Malang, diakses pada 04

${ }^{9}$ Ali, Sayuti, Metodologi Penelitian Agama Pendekatan Teori dan Praktek (Jakarta: Raja Grafindo Persada, 2002$), 63$.

.' Nurul Zuriah, Metodologi Penelitian Sosial dan Pendidikan Teori dan Aplikasi (Jakarta: PT Bumi Aksara, 2006),
} 
tujuan tertentu. ${ }^{11}$ Metode ini digunakan untuk menggali data yang berkaitan dengan pelaksanaan Manajemen humas di MTs. Ihyaul Ulum Bluri, sedangkan objek yang diwawancarai adalah kepala sekolah, Waka humas, Wali murid, dan sebagai pelengkap adalah para stakeholder MTs. Ihyaul Ulum Bluri.

c. Metode Dokumentasi

Dokumentasi adalah cara atau teknik yang dilakukan dengan mengumpulkan dan menganalisis sejumlah dokumen yang terkait dengan masalah penelitian. Dalam desain penelitiannya, peneliti harus menjelaskan dokumen apa yang dikumpulkan dan bagaiman cara mengumpulkan dokumen tersebut. Pengumpulan melalui dokumen bisa menggunakan alat kamera (video shooting), atau dengan cara fotokopi. ${ }^{12}$ Metode dokumentasi digunakan sebagai pelengkap dari penggunaan metode observasi dan wawancara. Metode ini digunakan untuk memperoleh data berupa dokumen seperti jumlah murid, struktur organisasi, letak geografis, profil MTs. Ihyaul Ulum Bluri dan data-data lain yang bersangkutan.

\section{Teknik Analisis Data}

Miles dan Huberman menyatakan bahwa analisis data kualitatif menggunakan kata-kata yang selalu disusun dalam sebuah teks yang diperluas atau dideskripsikan. Saat memberikan makna pada data yang dikumpulkan, data tersebut dianalisis dan diinterpretasikan. ${ }^{13}$ Setelah data didapatkan atau data yang sedang diperoleh perlu dianalisis apakah cocok dengan tema penelitian atau data tersebut bisa menjawab permasalahan dalam penelitian atau tidak. Dalam penelitian ini peneliti menggunakan analisis data yag dikemukakan oleh Miles dan Huberman yaitu model analisis interaktif. Model analisis interaktif mengandung empat komponen yang saling berkaitan yaitu; pengumpulan data, penyederhaan data, pemaparan data, dan penarikan serta pengujian simpulan. ${ }^{14}$ Analisis data dalam penelitian kualitatif dilalukan mulai sejak awal sampai sepanjang penelitian berlangsung. Penelitian ini menggunakan analisis data yang telah dikembangkan oleh Miles dan Huberman dengan menggunakan Analisis Model Interaktif melalui empat prosedur, yaitu:

a. Tahap Pengumpulan Data, Tahap ini merupakan proses pengumpulan data yang dilakukan oleh peneliti.

b. Reduksi data, dimaksudkan sebagai proses pemilihan, pemusatan perhatian pada penyerderhanaan, pengabstrakkan dan transfirmasi data "kasar" yang muncul dari catatan- catatan tertulis di lapangan/lokasi penelitian.

c. Penyajian data, artinya sebagai sekumpulan informasi tersusun yang memberikan kemungkinan adanya penarikan kesimpulan dan pengambilan tindakan. Dengan melihat penyajian- penyajian kita dapat memahami apa yang sedang menjadi dan apa yang harus dilakukan.

d. Menarik kesimpulan atau verifikasi, merupakan proses kegiatan dari menentukan kesmpulan yang utuh selama penelitian berlangsung. Sedangkan verifikasi merupakan kegiatan pemikiran kembali yang melintas dalam pemikiran penganalisis selama peneliti mencatat, atau tinjauan ulang pada catatan-catatan lapangan.

\section{Findings and Discussion}

Setelah peneliti mendapatkan data yang dibutuhkan, baik hasil dari observasi, wawancara maupun dokumentasi, pada poin ini akan peneliti paparkan uraian analisis data sesuai dengan rumusan masalah

. ' Deddy Mulyana, Metodologi Penelitian Kualitatif, (Bandung: PT Remaja Rosdakarya, 2006), 180

ir Amri Darwis, Metode Penelitian Pendidikan Islam: Pengembangan Ilmu Paradigma Islami, (Jakarta: Rajawali Press,

.' M. Djunaidi Ghony dan Fauzan Almanshur, Metodologi Penelitian Kualitatif ( Yogyakarta : Ar Ruzz, 2012 ), 306

's Mudjia Raharjo, "Materi kuliah Metodologi Penelitian Kualitatif”, Pascasarjana UIN Maliki Malang, diakses pada 
yang diambil serta tujuan penelitian. Pada analisis kali ini, peneliti akan mengintegrasikan kejadian yang ada dilapangan denga teori-teori serta menjelaskan hasil dari penelitian kali ini.

\section{Strategi Hubungan Masyarakat (Humas) dalam meningkatkan Partisipasi Aktif Wali Murid di MTs Ihyaul Ulum Bluri Solokuro Lamongan}

\section{a. Perencanaan (Planning)}

MTs. Ihyaul Ulum Bluri telah melaksanakan perencanaan dengan baik sesuai dengan teori perencanaan program yaitu menetapkan tujuan dan program-program kegiatan tertentu. Perencanaan kegiatan dilakukan pada rapat kerja pada awal bulan pembelajaran. Kegiatan perencanaan menjadi strategi yang harus dibuat dan dilaksanakan, sebagai patokan dalam melaksanakan kegiatan sehingga usaha pencapaian tujuan dari lembaga pendidikan dapat efektif dan efisien. Pada perencanaan humas di MTs. Ihyaul Ulum Bluri meliputi kegiatan perumusan tujuan dan identifikasi. Pada rapat kerja rapat kerja awal bulan, bidang humas sudah punya perencanaan program yang sudah disusun dan dikoordinasikan dengan kepala sekolah dan wakil kepala madrasah yang lain agar sesuai dengan visi dan misi sekolah serta aspirasi masyarakat dan wali murid.

Sebuah perencanaan kegiatan humas di MTs. Ihyaul Ulum Bluri berdasarkan dari kebutuhan masyarakat, baik internal dan eksternal . internal yang dimaksud para pegawai, guru, siswa, dan kepala sekolah, sedang eksternal pihak masyarakat, tokoh masyarakat, wali murid dan lingkungan sekitar. Hal tersebut sesuai dengan teori tujuan diselenggarakannya hubungan masyarakat dan sekolah.

Tujuan diselenggarakannya hubungan masyarakat dan sekolah di MTs. Ihyaul Ulum Bluri adalah untuk :

1) Mengenalkan pentingnya sekolah bagi masyarakat. Dalam hasil observasi angket untuk responden masyarakat menjelaskan bahwa humas menyampaikan informasi atau pesan dari sekolah ke masyarakat. ${ }^{15}$

2) Mendapatkan dukungan dan bantuan moral maupun finansial yang diperlukan bagi pengembangan sekolah. Dalam hasil wawancara untuk responden masyarakat menjelaskan bahwa mendukung kegiatan-kegiatan tersebut untuk kemajuan pendidikan.

3) Memberikan informasi kepada masyarakat tentang inti dan pelaksanaan program sekolah. Dalam hasil observasi angket untuk responden masyarakat menjelaskan bahwa humas memberikan keterangan informasi dengan jelas dan lengkap kepada masyarakat dan pihak terkait. ${ }^{16}$

4) Memperkaya atau memperluas program sekolah sesuai dengan perkembangan dan kebutuhan masyarakat.

5) Mengembangkan kerja sama yang lebih erat antara keluarga dan sekolah dalam mendidik anak-anak. Dalam observasi angket untuk responden masyarakat menjelaskan bahwa humas mendengarkan berbagai aspirasi, saran dan keluhan dari masyarakat dengan seksama dan penuh perhatian. ${ }^{17}$

Perencanaan humas dalam meningkatkan partisipasi wai murid yang dilakukan oleh MTs. Ihyaul Ulum Bluri telah sesuai sebagaimana mestinya, selain menyusun program berdasarkan hasil evaluasi program humas sebelumnya Humas MTs. Ihyaul Ulum Bluri juga melaksanakan rencana humas sesuai dengan program kerja humas.

\footnotetext{
10 Observasi, di MTs Ihyaul Ulum Bluri, 17 Juli 2021

17 Observasi, di masyarakat desa Bluri Solokuro Lamongan, 17 Juli 2021

'v Observasi, Wali Murid MTs Ihyaul Ulum Bluri, 17 Juli 2021
} 


\section{b. Pelaksanaan (Actuating)}

Pelaksanaan adalah keseluruhan usaha, cara, teknik, dan metode untuk mendorong para anggota organisasi agar mau dan ikhlas bekerja dengan sebaik mungkin demi tercapainya tujuan organisasi dengan efisien, efektif, dan ekonomis. ${ }^{18}$ Selain itu pelaksanaan berupaya untuk menjadikan perencanaan menjadi kenyataan, dengan berbagai pengarahan dan motivasi agar setiap karyawan dapat melaksanakan kegiatan sesuai dengan peran, tugas dan tanggungjawabnya.

Pelaksanaan humas dalam meningkatkan partisipasi masyarakat di MTs. Ihyaul Ulum Bluri sudah melaksanakan apa yang telah direncanakan oleh pihak sekolah. Humas di MTs. Ihyaul Ulum Bluri selalu menginformasikan kegiatan yang hendak dilakukan disekolah. Baik itu kepada masyarakat internal maupun eksternal.

Untuk menyampaikan informasi kegiatan dengan masyarakat eksternal khususnya dengan orang tua murid, humas MTs. Ihyaul Ulum Bluri menggunakan beberapa cara/alat bantu, yaitu; melalui pembuatan majalah, pengabdetan website, pembuatan brosur, nomor telepon, kotak saran, melalui edaran, melalui kegiatan spiritual dengan mengundang wali murid. Jadi, bisa dikatakan informasi tersebut saling melengkapi, penggabungan beberapa cara tersebut sangat efektif, mengingat biasanya banyak siswa yang lupa memberikan selebaran yang diberikan sekolah. Bila hal tersebut terjadi, maka orang tua dan masyarakat masih tetap mendapatkan informasi melalui website, situs online yang disebarkan oleh pihak MTs. Ihyaul Ulum Bluri.

Penginformasian sekolah kepada masyarakat luas seperti calon peserta didik baru, sekolah memanfaatkan media sosial. Pembuatan website dan media sosial sekolah menjadi modal utama untuk menginformasikan kegiatan sekolah kepada masyarakat dan pihak-pihak yang membutuhkan kelengkapan informasi. disamping penggunaan brosur dan spanduk (Banner). Pemilihan media internet untuk pemanfaatan teknologi yang digunakan sekolah sangatlah tepat. Mengingat saat ini teknologi semakin maju. Tidak orang yang tidak bisa membuka link di internet.

Selain bertujuan untuk menjembatani pihak madrasah dengan masyarakat dalam menjalin komunikasi, dua bertujuan untuk memudahkan madrasah dan masyarakat dalam hal berkoordinasi, bekerjasama dan kemitraan, misal koordinasi dalam banyak hal koordinasi dan kerjasama dalam kegiatan kemadrasahan seperti kesiswaan khususnya wali peserta didik, organisasi sosial, organisasi keagamaan. Karena, pada dasarnya manajemen hubungan sekolah dengan masyarakat merupakan kegiatan untuk membantu terciptanya tujuan, visi, misi bisa terealisasikan.

Penambahan kerjasama dalam bidang humas di MTs. Ihyaul Ulum Bluri menjadi salah satu hal yang sangat menarik. Karena, selain fokus pada informasi yang dilakukan sekolah terhadap masyarakat, MTs. Ihyaul Ulum Bluri juga merasa perlu untuk menjalin kerjasama dengan berbagai pihak. Komunikasi dan kerjasama yang dilakukan bertujuan untuk memenuhi kebutuhan siswa disekolah dan memajukan sekolah. Program dibagian kegiatan humas di MTs. Ihyaul Ulum Bluri telah melaksanakan:

1. Partisipasi tenaga/fisik dalam berbagai kegiatan.

2. Partisipasi Ide/Pemikiran

3. Partisipasi Dana

Hal tersebut sangat membantu mengenalkan sekolah beserta program kegiatannya kepada masyarakat serta dapat meningkatkan partisipasi masyarakat.

^^ Daryanto, Administrasi dan Manajemen Sekolah, (Jakarta : Rineka Cipta, 2013), 88. 


\section{c. Evaluasi (Evaluating)}

Evaluasi merupakan proses yang dilakukan untuk memastikan seluruh rangkaian kegiatan yang telah direncanakan, diorganisasikan, dan diimplementasikan bisa berjalan sesuai dengan target yang diharapkan. ${ }^{19}$ Pada dasarnya, kegiatan evaluasi merupakan kegiatan untuk mengatur pekerjaan yang direncanakan dan memastikan bahwa pelaksanaan pekerjaan tersebut berlangsung sesuai rencana atau tidak. Kalau tidak sesuai dengan rencana maka perlu adanya perbaikan. Di samping itu, humas memiliki sarana perlengkapan kantor untuk menunjang pekerjaan administrasi.

Kegiatan evaluasi di MTs. Ihyaul Ulum Bluri dimaksudkan untuk menjaga kegiatan agar sesuai dengan rencana yang telah ditetapkan. Evaluasi dilaksanakan oleh humas MTs. Ihyaul Ulum Bluri dengan dua cara, yaitu: evaluasi langsung dan per enam bulan atau satu semester (sebelum semester gasal, setelah semester gasal, dan menjelang kenaikan kelas). Yang melakukan evaluasi terdiri dari Kepala Sekolah dan Waka Humas. Setelah selesai kegiatan akan membuat laporan evaluasi kegiatan. Dengan adanya evaluasi maka pelaksanaan lebih terarah dan terkontrol dengan baik.

Karena program kegiatan semua sudah terlaksana seperti yang dijelaskan dilaporan evaluasi sebagai berikut:

1. Partipasi Aktif

a) Wali murid datang ketika diundang rapat dalam rangka a).orientasi siswa baru, b).dalam rangka menentukan rencana program kerja sekolah (RKS) c).penerimaan raport, d).rapat wali murid kelas 3 yang agendanya membicarakan persiapan menghadapi ujian nasional (UN), e).undangan bagi wali murid yang anaknya bermasalah baik masalah pribadi maupun masalah yang berkaitan dengan prestasi belajar siswa, f).acara sekolah khususnya peringatan hari besar agama (PHBI) maupun peringatan hari besar nasional (PHBN), dan g).undangan rapat penyerahan kembali kelulusan siswa.

b) Memberikan masukan/ saran dan bahkan kritikan bila ada agenda rapat yang sekiranya memberatkan siswa atau wali murid.

c) Peran serta Pihak Madrsah dan wali murid dalam rapat penyusunan RKS dan penyusunan agenda kegiatan, kemudian menyetujui program tersebut.

d) Peran serta masyarakat dan wali murid dalam menjaga keamanan sekolah dan keamanan siswa di sekitar sekolah.

\section{Partisipasi Pasif}

a) Wali murid mendampingi belajar anaknya, mengontrol belajarnya, dan bahkan mengajari mengerjakan pekerjaan rumah (PR).

b) Merasa ikut bertanggung jawab terhadap keberhasilan belajar anaknya.

c) Rajin berkomunikasi dengan guru wali kelas, untuk bertanya tentang belajar anaknya dan prestasi belajarnya.

d) Faktor-faktor yang mempengaruhi masyarakat ikut berpartisipasi dalam pengambilan keputusan dan perencanaan program di sekolah.

Evaluasi yang dilakukan diatas dapat memberikan suatu pengalaman yang baik dan meningkatkan keberhasilan program-program kegiatan yang telah ditetapkan sekolah.

\footnotetext{
${ }^{19}$ Ernie Tisnawati Sule \& Kurniawan Saefullah, Pengantar Manajemen, (Jakarta: Kencana, 2009), 6.
} 
2. Faktor Pendukung dan Penghambat Strategi Hubungan Masyarakat (Humas) dalam Meningkatkan Partisipasi Aktif Wali Murid di MTs. Ihyaul Ulum Bluri Solokuro Lamongan

Setiap lembaga pendidikan tentunya memiliki ciri tersendiri dalam pengolahan programprogram yang ada dilembaga. Dan juga tentunya setiap lembaga pendidikan dihadapkan dengan berbagai permasalahan-permasalahan. Begitu pula di lembaga MTs. Ihyaul Ulum Bluri, jika permasalahan yang dihadapi itu menjadi faktor penghambat yang dapat mempengaruhi keberlangsungan program-program yang diterapkan oleh lembaga, maka akan diimbangi dengan faktor pendukung yang ada dilembaga.

\section{a. Faktor Pendukung}

Adapun faktor-faktor pendukung strategi humas dalam meningkatkan partisipasi aktif wali murid setelah dilakukan wawancara sesuai dengan yang telah dipaparkan diatas, sebagai berikut :

1) Antusias wali murid dalam mendukung kegiatan sekolah

Wali murid yang sangat antusias merupakan faktor pendukung yang memiliki nilai tersendiri. Kemajuan mutu yang ada dilembaga pendidikan tidak terlepas dari partisipasi dari wali murid tersebut. Untuk meningkatkan partisipasi wali murid di MTs. Ihyaul Ulum Bluri, maka diadakan program humas yang mana akan membantu wali murid untuk bisa berpartisipasi secara maksimal serta proses yang berlangsung hingga membuahkan hasil. Apabila hasil dari program kehumasan tersebut baik kualitas lembaga pendidikan juga pasti akan baik. Salah satu komponen yang menjadikan pendidikan bermutu adalah wali murid. Semakin bertambahnya keantusiasan wali murid dalam mengikuti kegiatan, maka dapat disimpulkan bahwa kegiatan tersebut disukai dan dinikmati oleh wali murid dan itu menandakan bahwa program humas tersebut berhasil untuk diterapkan. Oleh karena itu, antusias wali murid dalam setiap kegiatan menjadi semangat demi menjadikan lembaga pendidikan yang berkualitas.

2) Rasa memiliki dan semangat dari warga sekolah

Rasa memiliki dan semangat luar biasa yang ditunjukan dari warga sekolah terhadap lembaga pendidikan juga merupakan salah satu faktor pendukung bagi terlaksananya program humas. Dilihat dari antusiasnya wali murid maka akan mempengaruhi semangat dari warga sekolah. Semangat dalam mengikuti, mengawasi dan mengarahkan wali murid dalam meningkatkan partisipasi nya terhadap lembaga pendidikan.

3) Ikatan persaudaraan yang kuat

Setalah mempunyai semangat yang luar biasa sebagai pendukung sekolah juga mempunyai ikatan persaudaraan yang kuat. Hal ini menjadi keunikan tersendiri bagi lembaga pendidikan. Di ibaratkan apabila sekolah mengalami hal yang membanggakan, maka seluruh warga sekolah tak terkecuali wali muird ikut merasa bangga. Dan apabila sekolah sedang mengalami kesusahan dalam bentuk apapun, seluruh warga sekolah akan ikut serta dalam membantu. Hal ini tak terlepas dari tujuan di dirikannya sekolah tersebut, yaitu sebagai lembaga pendidikan yang mampu memberikan pembelajaran kepada masyarakat.

\section{b. Faktor Penghambat}

Adapun faktor-faktor penghambat strategi humas dalam meningkatkan partisipasi aktif wali murid setelah dilakukan wawancara sesuai dengan yang telah dipaparkan diatas, sebagai berikut :

1) Kurangnya pengetahuan dunia digital wali murid 
Perkembangan Teknologi Informasi dan Komunikasi begitu cepat dan kemajuannya yang begitu pesat tidak bisa dihindarkan. Perangkat teknologi seperti komputer, gadget seluler, dan internet sangat penting dalam kehidupan sehari-hari dan menggunakan teknologi itu bukan lagi barang mewah bagi kita, tetapi suatu keharusan. Perkembangan TIK yang cepat berpengaruh besar terhadap semua bidang kehidupan manusia, termasuk di bidang pendidikan. Di era disrupsi ini semua perlu dibekali tentang dunia digital, tak terkecuali wali murid. Agar bisa mengakses segala informasi di internet. Karena hampir mayoritas semua lembaga pendidikan dari dasar sampai perguruan tinggi menggunkan internet sebagai suatu alat yang bisa digunakan untuk berbagai kegiatan, salah satunya publikasi tentang kegiatan yang ada di sekolah. Dari penjelasan tersebut. Maka diperlukan adanya edukasi kepada wali murid untuk bisa beradaptasi dengan hal tersebut sehingga memudahkan pencapain tujuan dalam program humas.

2) Kurangnya pendanaan dan fasilitas

Dana menjadi faktor penghambat utama dalam meningkatkan partisipasi aktif wali murid di MTs. Ihyaul Ulum Bluri. Karena melihat masih banyaknya sarana prasarana penunjang kegiatan humas yang perlu diperbaiki dan disediakan. Semuanya menjadi terbengkalai karena kurangnya dana pendidikan. Oleh karena itu, diperlukan penyusunan anggaran untuk memperhatikan ketersediaan dana yang akan digunakan untuk penyelenggaraan program humas, penentuan skala prioritas sangat penting dilakukan oleh humas sekolah pada saat perumusan anggaran program humas sekolah. Dengan adanya penentuan skala prioritas maka humas sekolah dapat mengatur anggaran dana yang lebih besar untuk kegiatan yang memiliki sasaran program humas yang cakupannya lebih luas, sedangkan untuk penyelenggaraan program humas yang cakupannya lebih sempit maka mempergunakan dana yang lebih kecil. Selain itu, penentuan skala proiritas dalam penyusunan anggaran juga mempertimbangkan besaran dana yang harus dikeluarkan untuk memenuhi kebutuhan media atau peralatan yang harus digunakan dalam penyelenggaraan program humas.

3) Kurang profesionalitas praktisi humas.

Faktor penghambat yang tidak terlalu kelihatan akan tetapi memiliki dampak yang signifikan yakni kurang profesionalnya seorang praktisi humas yang ada dilembaga pendidikan. Dalam menjalankan program kehumasan seorang praktisi humas dituntut untuk memiliki komptensi diantaranya : Mampu mengekspresikan pendiriannya dan mengetaui kapan harus mendengar, Mampu berpikir rasional, efektif dan efisien dalam keadaan darurat (kritis) dan dapat mengambil keputusan yang cepat, profesional, sekaligus proporsioal, Menjadi pengamat yang baik, mampu mempelajari keadaan, situasi, kondisi tertentu, serta memiliki daya ingatan yang baik, sistematis dan kritis. Maka permasalahan tersebut harus diatasi dengan memberikan pelatihan dan mentor kepada praktisi humas sehingga tidak akan menghambat pada tujuan program-program humas.

\section{Kesimpulan}

Temuan penelitian yang dilakukan, berjudul "Strategi Hubungan Masyarakat (Humas) dalam Meningkatkan Partisipasi Aktif Wali Murid di MTs. Ihyaul Ulum Bluri Solokuro Lamongan maka peneliti dapat menyimpulkan hal-hal berikut:

1. Strategi Hubungan Masyarakat (Humas) dalam meningkatkan Partisiapasi Aktif Wali Murid di MTs. Ihyaul Ulum Bluri Solokuro Lamongan

a. Perencanaan (Planning)

Perencanaan humas dalam meningkatkan partisipasi aktif wali murid yang dilakukan di MTs Ihyaul Ulum Bluri dilakukan berdasarkan rapat kerja awal pembelajaran. Rapat kerja 
tersebut diikuti oleh para guru dan kepala madrasah. Dalam merencanakan sebuah program humas MTs. Ihyaul Ulum Bluri mengadakan analisis kebutuhan dan keinginan masyarakat baik internal maupun eksternal. Adapun rencana kegiatan humas MTs. Ihyaul Ulum Bluri sebagai berikut :

1) Partisipasi tenaga/fisik dalam berbagai kegiatan

2) Partisipasi ide/pikiran

3) Partisipasi dana

b. Pelaksanaan (Aktuating)

Pelaksanaan program humas untuk meningkatkan partisipasi aktif wali murid di MTs. Ihyaul Ulum Bluri dilaksanakan sesuai dengan jadwal yang telah ditentukan yaitu:

1) Partisipasi tenaga/fisik dalam berbagai kegiatan

a) Komite Sekolah selalu mengontrol pelaksanaan program sekolah.

b) Wali murid yang menjadi tenaga kerja dibangunan gedung sekolah.

c) Sumbangan tanah dari H. Umar

d) Bekerjasama dengan seluruh organisasi dan komunitas yang ada didesa bluri.

e) Adanya keterlibatan dari masyarakat.

2) Partisipasi ide/pikiran

a) Ketua Yayasan selalu memberikan pertimbangan terhadap semua rencana program.

b) Orang tua yang berprofesi sebagai ustadz telah memberikan nasihat melalui kegiatan peringatan hari besar Islam (PHBI) dan peringatan hari besar nasional (PHBN).

c) Usulan, masukan, dan saran dari masyarakat sekitar.

d) diadakan seminar lokakarya yang berkaitan dengan strategi pembelajaran.

e) Ormas dari berbagai kalangan yang ada di desa menyumbangkan ide atau pemikiran kepada lembaga pendidikan dan ikut serta dalam pembinaan karakter.

f) Pemerintahan desa ikut serta bertanggung jawab terhadap keselamatan dan keamanan peserta didik.

3) Partisipasi dana

a) Partisipasi berbentuk sumbangan berupa pembayaran SPP setiap bulan.

b) Pemerintah. Sumbangan pemerintah berupa dana operasional sekolah (BOS).

c) Beasiswa program Kartu Indonesia Pintar (KIP) bagi peserta didik yang tercatat sebagai pemilik kartu.

Adapun program yang mendorong partisipasi yang dilakukan oleh sekolah sebagai berikut:

a. Internet

b. Kunjungan/Study Banding

c. Bimbingan Tilawatil Qur'an

d. Bimbingan Belajar

e. Pondok Pesantren

c. Evaluasi (Evaluating)

Dalam pelaksanaan evaluasi, MTs. Ihyaul Ulum Bluri melakukan rapat per 6 bulan yakni, sebelum semester gasal, setelah semester genap, menjelang kenaikan kelas. Evaluasi kegiatan humas di MTs. Ihyaul Ulum Bluri dilakukan untuk membandingkan program yang telah ditetapkan dengan pelaksanaan program tersebut. Bila dalam pelaksanaannya terjadi kesalahan, maka akan segera dikoreksi.

2. Faktor-faktor yang yang mempengaruhi strategi humas dalam meningkatkan partisipasi aktif wali murid di MTs. Ihyaul Ulum Bluri: 
Yogi Kurniawan Prasetyo

a. Faktor Pendukung

1. Antusias wali murid dalam mendukung kegiatan sekolah.

2. Rasa memiliki dan semangat dari warga sekolah.

3. Ikatan persaudaraan yang kuat.

b. Faktor Penghambat

1. Kurangnya pengetahuan dunia digital wali murid.

2. Kurangnya pendanaan dan fasilitas.

3. Kurang profesionalitas praktisi humas.

\section{Daftar Kepustakaan}

Amri Darwis, Metode Penelitian Pendidikan Islam: Pengembangan Ilmu Paradigma Islami, Jakarta: Rajawali Press, 2014.

Ary H. Gunawan, Administrasi Sekolah Administrasi Pendidikan Mikro, Jakarta: PT. Rineka Cipta, 1996.

Deddy Mulyana, Metodologi Penelitian Kualitatif, Bandung: PT Remaja Rosdakarya, 2006.

E.Mulyasa, Manajemen Berbasis Sekolah, Konsep Strategi dan Implementasi, Bandung: PT. Remaja Rosdakarya, 2003.

E.Mulyasa, Menjadi Kepala Sekolah Profesional, Bandung: PT. Remaja Rosdakarya, 2004.

Ernie Tisnawati Sule \& Kurniawan Saefullah, Pengantar Manajemen, Jakarta: Kencana, 2009.

Lexy J. Moleong, Metodologi Penelitian Kualitatif, Bandung: PT Remaja Rosdakarya, 2005.

M. Djunaidi Ghony dan Fauzan Almanshur, Metodologi Penelitian Kualitatif, Yogyakarta : Ar Ruzz, 2012.

Mudjia Raharjo, "Materi kuliah Metodologi Penelitian Kualitatif”, Pascasarjana UIN Maliki Malang, diakses

Nurul Zuriah, Metodologi Penelitian Sosial dan Pendidikan Teori dan Aplikasi, Jakarta: PT Bumi Aksara, 2006.

Soemirat, Dasar-Dasar Public Relations, Bandung: Remaja Rosdakarya, 2008.

Undang-undang Sistem Pendidikan Nasional, Yogyakarta: Pustaka Pelajar, 2005. 